\title{
The Giant African Land Snail (GALS) Archachatina marginata Egg and Adult Sizes: Case Study
}

Ejidike $\mathrm{BN}^{*}$ and Adewuyi CO

Department of Ecotourism and Wildlife, Federal University of Technology, Nigeria

*Corresponding author: Ejidike BN, Department of Ecotourism and Wildlife, Federal University of Technology, P M B 704, Akure, Nigeria, Tel: +2348034704604, E-mail: bndike@yahoo.com

Received Date: November 22, 2017; Accepted Date: May 24, 2018; Published Date: May 31, 2018

Copyright: (c) 2018 Ejidike BN, et al. This is an open-access article distributed under the terms of the Creative Commons Attribution License, which permits unrestricted use, distribution, and reproduction in any medium, provided the original author and source are credited.

\begin{abstract}
Investigations into relationships of eggs, hatchlings and adult of Giant African land snail Archachatina marginata were conducted to ascertain optimum size of the snail species for better performance in snail farming. The research was carried out at the Teaching and Research Farm of the Department of Ecotourism and Wildlife Management, Federal University of Technology, Akure, Ondo State, Nigeria. A total number of 80 adult giant African land snails of four different sizes were used in conducting the experiment. The 80 adults of Archachatina marginata were weighed, grouped into four according to weight and labeled treatments A-D. (A- 100-249 g, B- 250-349 g, C- 350-449 g and D- 450-549 g). The snails in each group were duplicated and stocked into wooden cages of dimension $60 \mathrm{~cm} \times$ $50 \mathrm{~cm} \times 45 \mathrm{~cm}$ and filled with loamy soil up to $15 \mathrm{~cm}$ thickness. The Giant African land snail A. marginata in each group were fed ad libtum with plant food materials for 90 days during the rainy season. Archachatina marginata eggs were searched for daily in the enclosure of each group, collected eggs were weighed, egg length and width measured, and incubated group by group. Hatchlings from the incubated eggs each group were collected, weighed, shell length and width measured and recorded accordingly. The results indicated that the GALS A. marginata Group $D$ laid the eggs that had the highest mean weight $(5.3 \pm 0.1 \mathrm{~g})$, mean length $(2.5 \pm 0.1 \mathrm{~cm})$ and mean width $(1.9 \pm$ $0.1 \mathrm{~cm})$. While those Group A laid the smallest eggs that had the lightest mean weight $(2.8 \pm 0.1 \mathrm{~g})$, mean length $(2.1 \pm 0.1 \mathrm{~cm})$ and mean width $(1.5 \pm 0.1 \mathrm{~cm})$. Significant differences $(p<0.05)$ existed among each of the parameters of weight, length, and width of the eggs from adult Archachatina marginata in all the treatment groups, this pointing to the dependency of egg characteristics of Archachatina marginata on the adult that laid the eggs. Similar incubation period of 30 days was recorded in all the groups. The hatchlings weight, length and width were found to depend on the eggs weight, length and width of $A$. marginata incubated.
\end{abstract}

Keywords: Archachatina marginata; Adults; Eggs; Hatchlings; Relationship

\section{Introduction}

The Giant African Land Snails are pulmonate, nocturnal, hermaphroditic gastropods of the Family Achatinidae. They are indigenous to Africa and are distributed in sub-Saharan Africa, ranging from the Gambia in the West to the Lake Chad region in the East. Their distribution extends southwards to the Orange River in South Africa [1]. African giant land snail (Archachatina marginata) is one of the largest known land snails in West Africa. Most land snails dwell naturally in the forest litters of dense tropical high forest to fringing riparian forests of the derived guinea savannah in Nigeria $[2,3]$. Land snails are non-timber products of forest that thrive under captive setting in humid environment. Many people use snail meat to complement their conventional and regular sources of animal protein. Nigeria is known to be richly endowed with different species of snails which vary in sizes, colors, adaptability and performance [4,5]. These land snail species include Archachatina marginata, Achatina achatina, Achatina fulica, Limcolaria spp, and other garden snails.

African giant land snails are considered a delicacy in Nigeria and they command high demand in the market [6] nowadays the snail is being reared and gathered for its value in both rural and international markets. Snail species by-products mostly the shell hold lots of potential in the Nigerian livestock industries. Land snail species can serve as means of alleviating acute protein shortage, they have high rate of productivity and fecundity $[7,8]$. The low fat content in snail meat makes it a good antidote for fat-related diseases such as hypertension and is readily accepted by many people recommended the incorporation of other alternative animal protein sources such as cane rats, giant rat and various species of the African giant land snail into farming strategies for poverty alleviation and control of short fall in animal production $[3,9]$. The good potential of land snails as animal protein has been exploited in some European countries notably in Italy, Taiwan and Korea. The rearing of African giant land snail Achatina fulica in Taiwan and Philippines and Achatina achatina in Britain increased the world import - export trade in live and canned snail from \$36 million and \$17 million respectively in 1978 to \$54 million and $\$ 32.5$ million for the same product in 1988 [10]. It is high time large commercial farming of these land snail species started in order to produce enough animal meat on the table on daily basis. Research had conquered major obstacles in farming of land snail species in the tropical environment, hence in rearing of land snails nowadays the animal will continue to grow throughout the year and reproduce all year round $[11,12]$.

Picking of land snails from the wild as well as its farming are good sources of income to peasant farmers as well as source of subsistence for them in the rural area of Southern Nigeria [13]. The aim of this study was to determine the dependency of $A$. marginata egg size on adult size as well as the dependency of hatchling size on the egg size, these information will be necessary for the sustainability of land snail 
Page 2 of 4

farming. Through this, farmers will know the appropriate size of adult snails to select as breeding stock for the farm.

The experiment was carried out at the Teaching and Research Farm of the Department of Ecotourism and Wildlife Management of the Federal University of Technology, Akure, Ondo State, Nigeria. The area lies within the tropical rainforest belt with an annual rainfall of about $1,613 \mathrm{~mm}$ per year and an annual mean temperature of about $27^{\circ} \mathrm{C}$. The study area is located on longitude $150 \mathrm{~N}$ and latitude $50 \mathrm{E}$. The dry season usually occurs between October and March while the raining season starts from April to September.

GALS $A$. marginata used for the experiment were purchased from rural market near the University, 80 in number. The snails were selected in four different sizes and bought. They were grouped into four and each group of $20 \mathrm{~A}$. marginata was duplicated and stocked in rearing cages constructed using wooden frames of dimensions $60 \mathrm{~cm} \times$ $45 \mathrm{~cm} \times 18 \mathrm{~cm}$ portioned into eight apartments. The cages were filled with loamy soil up to $15 \mathrm{~cm}$. The cages were randomly stocked 10 snails each. The inside cages filled with soil was regularly sprinkled with water so as to provide moist condition for easy burrowing and other activities of snail.

The experimental snail species were fed with the same plant food materials ad libtum. Each group of the experimental snails was regularly checked for eggs. The eggs lay in the various snail groups were searched for and the collected ones were weighed, length and width measured and recorded and incubated in the incubation medium prepared for each group. Hatchlings were checked in the incubation media from 25th day of incubation and collected hatchlings were weighed with Mc2000 Metlar electronic balance, shell length and width measured using thread and ruler. The hatchings collected from each group were stocked according to their group and reared for four weeks.

\section{Results}

Figure 1 presents the mean of the varying body weight of the GALS selected and used during the experiment. Table 1 presents the results of the mean egg weight, length, and width laid by the African giant land snails. Significant differences $(\mathrm{p}<0.05)$ existed among the mean weight of the eggs laid by $A$. marginata in all the treatments, Mean egg length and width of $A$. marginata followed the same trend of significance $(\mathrm{p}<0.05)$ as the weight. These eggs parameters from different size groups of $A$. marginata are also illustrated in Figure 2. Figures 3 and 4 present mean hatchlings weight, shell length and width obtained at hatching and at four weeks old from different size groups of $A$. marginata. The $A$. marginata eggs collected from different size groups and incubated in the different size groups had same mean incubation period of 30 days.

\begin{tabular}{|l|l|l|l|}
\hline Group & $\begin{array}{l}\text { Mean egg weight } \\
\mathbf{( g )}\end{array}$ & $\begin{array}{l}\text { Mean egg length } \\
(\mathbf{c m})\end{array}$ & $\begin{array}{l}\text { Mean egg width } \\
(\mathbf{c m})\end{array}$ \\
\hline A (100-249 g) & $2.8 \pm 0.1^{\mathrm{a}}$ & $2.1 \pm 0.1^{\mathrm{a}}$ & $1.5 \pm 0.1^{\mathrm{b}}$ \\
\hline B (250-349) & $3.7 \pm 0.1^{\mathrm{b}}$ & $2.3 \pm 0.1^{\mathrm{b}}$ & $1.7 \pm 0.1^{\mathrm{a}}$ \\
\hline C (350-449) & $4.8 \pm 0.1^{\mathrm{c}}$ & $2.4 \pm 0.1^{\mathrm{c}}$ & $1.8 \pm 0.1^{\mathrm{c}}$ \\
\hline
\end{tabular}

\begin{tabular}{|l|l|l|l|}
\hline$D(450$-above $)$ & $5.3 \pm 0.1^{\mathrm{d}}$ & $2.5 \pm 0.1^{\mathrm{e}}$ & $1.9 \pm 0.1^{\mathrm{d}}$ \\
\hline
\end{tabular}

Table 1: Giant African land snail eggs laid by different groups.

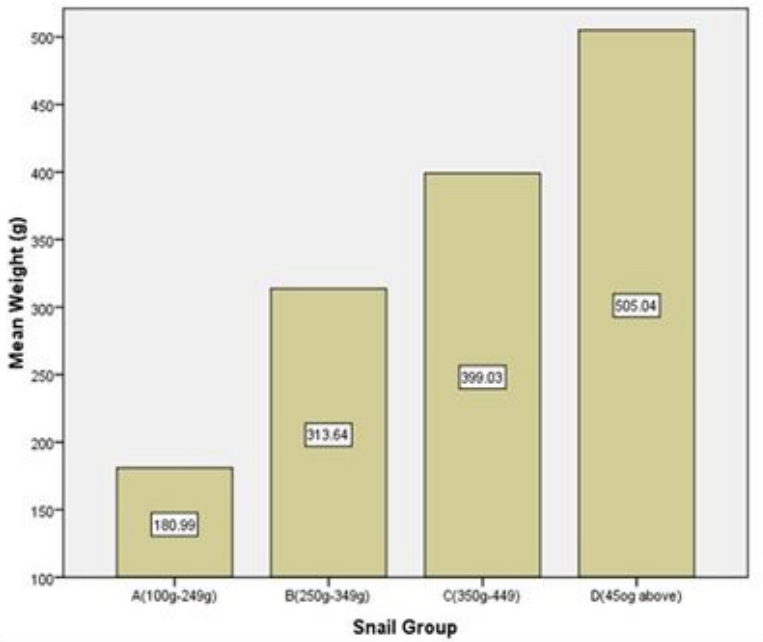

Figure 1: Histogram showing the mean weight of different group of A. marginata used during the experiment.

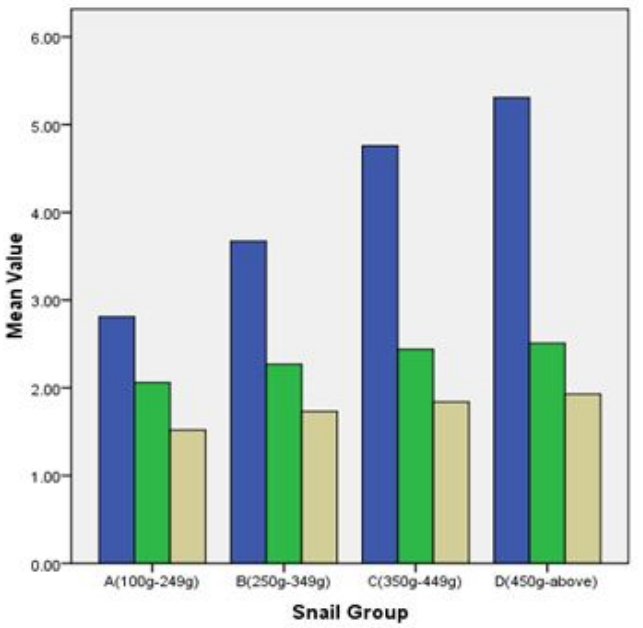

Egovesest(g) Egg Lenght (cm)
Gegghath $(\mathrm{cm})$

Figure 2: Histogram showing weight, length and width of $A$. marginata eggs collected from different sizes of the adult groups. 


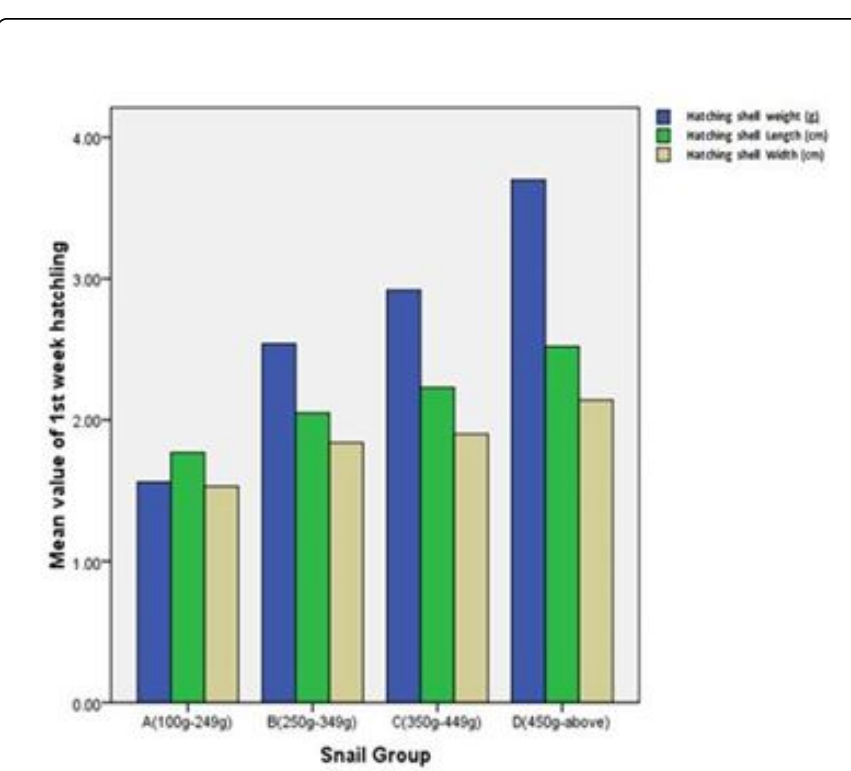

Figure 3: Histogram showing hatching shell's weight, length and width of $A$. marginata collected at hatchling.

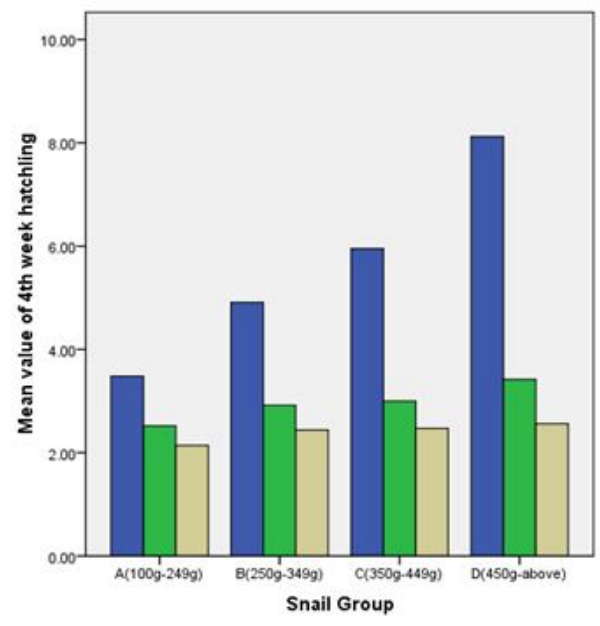

Figure 4: Histogram showing weight, length and width of $A$. marginata hatchling at end of four weeks.

\section{Discussion}

Snail farming is one of the recommendation of FAO that is now a popular and increasing practice in West Africa and according to Akinnusi $O$ [14] giant land snail can be reared as a mini-livestock to meet the demand of the people reported success in the use of artificial diet in feeding and in supplementing the natural food of African giant land snail with great success in growth and development of the animal [15-17].
The positive results obtained which showed that all Archachatina marginata in the four groups laid eggs during the experiment and their eggs that were incubated hatched, the hatchlings survived and increased in body weight and other body parameters when reared for four weeks proved the animal a species for investing into. From the observation in the results of the study the snail eggs laid by the $A$. marginata in different treatment groups during the study varied significantly $(\mathrm{p}<0.05)$ in weight, length and width showing that snail size/weight plays important role in the size/weight of the eggs it will lay. Also the hatchlings from the results are directly dependent on the egg size and indirectly dependent on the adult $A$. marginata that lay the eggs, hence such farmers should be instructed and educated on the size of adult African giant land snails to be selected as breeding/ producing stock for egg laying. The result on incubation period of average of 30 days in the entire group is similar with the report of $[13,18,19]$ which indicated that eggs of African giant land snail can hatch within 25-33 days of incubation. This proved that African giant land snail is a potential animal species that can multiple easily, and when properly harness can positively contribute towards meeting the protein requirements of teeming population in the country. The body parameters of adult $A$. marginata that laid eggs are in relation with the parameters of the eggs they laid as well as the hatchlings that came up from the eggs. It is clearly observed that those eggs whose parent body weight were within the group of $450 \mathrm{~g}$ and above have the highest egg weight as well as hatchling weight while the least fall within the group $100-249 \mathrm{~g}$ proving dependency of snail eggs weight on the parent snail that laid it. This is noted on the mean body weight of the hatchlings at different treatment group differing significantly $(\mathrm{p}<0.05)$. This difference in body weight of the hatchlings obtained at hatching point is not unexpected because the weight and size of the eggs from different treatment group were not the same. From the hatchlings raised it was observed that all the hatchlings from the treatments increased in weight, length and width. However, there were significant differences $(p<0.05)$ among the weight; and among other parameters of the hatchlings from the treatment groups. This showed that during the growth, there was progressive weight, length and width increase though with significant differences $(\mathrm{P}<0.05)$ between the snail from different size groups.

\section{Conclusion}

The results of this study showed that during the hatchling (juvenile) phase of growth, there was progressive weight, length and width increment with significant difference $(\mathrm{P}<0.05)$ between the hatchling of the groups. However, the results of this study should guide breeders in the selecting of breeding stocks, thus increasing the availability of animal protein thereby contributing positively to food security.

\section{References}

1. Hodasi JKM (1998) Life history studies of Archatina achatina (Linne). Journal Molluscan studies 45: 328-339.

2. Imevbore EA (1990) Management technique in rearing the African giant land snail Archachatina marginata Swainson. Pp $288 \mathrm{PhD}$. Thesis submitted to the university of Ibadan Nigeria.

3. Adeniyi B, Shobanke IA, Omotoso AB (2013) Economic Analysis of Snail Meat Consumption in Ibarapa Central Local Government Area of Oyo State. J Mark Cons Res 2.

4. Amusan JA, Omidiji MO (1999) Edible land snail: A technical guide to snail farming in the tropic. Verify Printer Limited, Ibadan. Pp 5-50.

5. Ibom LA (2009) Variations in reproductive and growth performance traits of white-skinned $\mathrm{x}$ black skinned African giant land snail hatchlings 
Citation: Ejidike BN, Adewuyi CO (2018) The Giant African Land Snail (GALS) Archachatina marginata Egg and Adult Sizes: Case Study. J

Archachatina marginata Swainson in Obubra, Nigeria. Ph.D Thesis Department of Animal Science, University of Calabar, Nigeria.

6. Adeyeye EI (1996) Waste yield, Proximate and Mineral Composition of three different types of land snail found in Nigeria. Int J Food Sci Nutr 42: 111-116.

7. Ibom LA, Okon B, Essien A (2008) Morphometric analysis of eggs laid by two ecotypes of snails Archachatina marginata (Swainson) raised in captivity. Glob J Agri Sci, 7: 119-121.

8. Okon B, Ibom LA (2012) Snail breeding and snailery management Fresh Dew Productions. Calabar, Nigeria. Pp 90.

9. Food Agriculture Organization (1986) Farming snail: Learning about Pen building, Food and Agricultural of USA. Better farming series 33 .

10. Elmslie LJ (1989) Snails \& Snail farming. World animal review 41: Pp 20-26.

11. Ejidike BN, Omisade IA (2007) Evaluation of dry season rearing of African giant land snail (Archachatina marginata) on different food types and apartments. J Fish Aqua Sci 2: 361-365.

12. Dododawa Z, Ejidike BN, Adeyemo AI (2017) Influence of intensive and semi intensive management on the growth and reproductive performance of Archachatina marginata.

13. Ejidike BN, Afolayan TA, Alokan JA (2002) Influence of food and season on egg production of African Giant Land Snail (Archachatina marginata).
In proceeding of the 27th Annual Conference Nigeria society for animal Production (NSAP), FUTA Nigeria Pp 309-311.

14. Akinnusi O (1997) Snail farming; Low investment and high profit business. Livestock Echo Pp 11-23.

15. Ejidike BN (2001) Comparative effect of supplemental and complete diets on the performance of African giant land snail (A. marginata). In Proceeding of the 26th Annual conference of the Nigerian society for Animal production 26: 151-153.

16. Ejidike BN (2009) Assessments on the performance of Archachatina marginata reared on plant or supplemented plant leaves. Applied Tropical Agriculture Nigeria 14: 124-128.

17. Ejidike BN (2010) African giant land snail culture in Nigeria. Applied Tropical Agriculture 15: 43-45.

18. Agbelusi EA, Adeparusi EO (1999) Egg incubation period and hatching success of the African giant land snail (Achachatina marginata) (Swainson 1777) in different incubation media. J App Anim Res 15: 57-62.

19. Stievenart C (1996) Shell morphology, Growth reproduction and Aestivation by African snails: Laboratory observation Arachachatina marginata suturalis: Achatina achatina and Achatina fulica $\mathrm{PhD}$ thesis no 5, pp 206. 